\title{
TURKEY'S RENEWABLE ENERGY OUTLOOK AND A GENERAL ASSESSMENT OF RECENT DEVELOPMENTS
}

\author{
Fatma Canka Kilic $^{1 *}$, Mehmet Keskin Kilic ${ }^{1}$, Muharrem Eyidogan², Durmus Kaya ${ }^{2}$ \\ ${ }^{1 *}$ Department of Electrical and Energy, Kocaeli Vocational School, Kocaeli University, Kullar Beldesi, \\ Mahmutpaşa Cad., No: 1, P.K.: 41140, Kullar/Başiskele/Kocaeli, Turkey; \\ ${ }^{2}$ Department of Energy Systems Engineering, Faculty of Technology, Kocaeli University, 41380 Umuttepe, Kocaeli, \\ Turkey;
}

*Corresponding author Fatma Canka Kilic, e-mail: fatmacanka@ hotmail.com; Received June, 2018; Accepted July, 2018; Published January, 2019;

DOI: https://doi.org/10.31407/ijees9101

\begin{abstract}
Turkey is the world's 17th and Europe's 6th largest economy and the country has made significant advances and breakthroughs in its economy since last two decades. Turkey is a very rich country in terms of geographical location and geological structure due to renewable energy sources. The country has planning to take advantage of these resources to the maximum extent aiming both will contribute to security of energy supply and prepare the ground for the creation of new jobs. The installed power of renewable energy sources, which was 12,305 MW in 2002, has reached the value of 36,702 MW in the third quarter of 2017 with an increase of 198\%, approximately. This is an indicator that the renewable energy can be a solution to achieve the country's future goals of energy. This paper presents an overview of Turkey's renewable energy appearance and a general examination of renewable energy status with the latest figures, which determined according to the recent developments. It is also aimed to contribute to all fields, businesses and the industry working on renewable energy, not only to whom seeking the newest developments and latest numbers, but also planning to produce green energy and create green jobs for the country's sustainable development.
\end{abstract}

Key words: Renewable Energy, Turkey, Energy Developments 